\title{
Diversity, density and community structure of the demersal fish fauna of the continental slope off western Australia (20 to $\left.35^{\circ} \mathrm{S}\right)$
}

\author{
Alan Williams*, J. Anthony Koslow, Peter R. Last \\ CSIRO Marine Research, GPO Box 1538, Hobart, Tasmania 7001, Australia
}

\begin{abstract}
The first survey of the continental-slope demersal fish fauna off the west coast of Australia - the region between latitudes 20 to $35^{\circ} \mathrm{S}$ in depths from 200 to $1500 \mathrm{~m}$ - was undertaken in 1991. Most species were caught rarely and only 14 species were represented by $>1 \%$ of individuals in the total catch. Collectively, the catches were dominated numerically by the Acropomatidae and Chlorophthalmidae at shelf-break and upper slope depths ( 200 to $600 \mathrm{~m})$, and the Macrouridae, Bathygadidae, Synaphobranchidae, Alepocephalidae and Oreosomatidae at greater depths. Overall, the Macrouridae was both the most abundant and most species-rich family. The fauna appears to be richer (388 species from 109 families) than the slope faunas of the more intensively sampled North Atlantic and northern Pacific; its richness may be attributable to the overlap of ancient and extensive Indo-West Pacific and temperate Australasian faunas that extend from shelf to mid-slope depths. These faunas are maintained in the region by a variety of near-surface and intermediate-depth ocean currents that bathe the western slope. Seven distinct fish community types were defined by bathymetric and latitudinal boundaries: a northern and a southern shelf-break community; 2 depth-stratified communities on the upper-slope, and 3 communities defined by depth and latitude on the midslope. Ecotones between these communities at the 250 to $350 \mathrm{~m}$ and 700 to $800 \mathrm{~m}$ depth intervals coincide, respectively, with the lower limits of the near-surface Leeuwin Current and the upper extent of Antarctic Intermediate Water. The composition of the mid-slope fauna in the southern part of the study area suggests it is part of a wide-ranging Australasian mid-slope community shared with the Great Australian Bight, southeastern Australia and New Zealand. There is progressive replacement by a northern fauna at all depths as latitude decreases along the west coast. The western slope fauna is characterised by low density as well as high diversity. Fish density was estimated to be several times lower than on the continental slope off southeastern Australia, and also lower than North Atlantic and northern Pacific slope regions. Low density is likely to be related to low overlying productivity due to the absence of upwelling associated with the near-surface, southward-flowing Leeuwin Current. Low overlying productivity also appears to be linked to the ecological composition of the demersal fauna; it is characterised by many relatively small, benthic species, non-vertically migrating species, and a lack of aggregated large commercial fishes.
\end{abstract}

KEY WORDS: Demersal fish · Continental slope $\cdot$ Western Australia $\cdot$ Diversity $\cdot$ Species richness · Density $\cdot$ Community structure $\cdot$ Productivity

\section{INTRODUCTION}

The composition and spatial distributions of the fish fauna of the continental slope ( $>200 \mathrm{~m}$ depth) in Australian waters was virtually unknown until the mid1980s, apart from a short account from the southeast-

*E-mail: alan.williams@marine.csiro.au ern Australia slope (Last \& Harris 1981). Unlike other slope regions for which there are extensive data, e.g. the North Atlantic Ocean (Haedrich \& Merrett 1988) and the northern Pacific Ocean (Pearcy et al. 1982), Australia's slope regions had not been surveyed. The impetus for studies of the biomass, diversity and structure of slope fish communities was provided by the development of commercial fisheries at upper and 
mid-slope depths (May \& Blaber 1989, Newton \& Klaer 1991, Koslow et al. 1994, Kloser et al. 1996).

Initially, this focus was on Australia's southeastern region, leaving its extensive western coastline poorly known - in particular, the offshore waters were virtually unsampled from an ichthyological perspective (Paxton et al. 1989). Catch information existed only on commercial fishes from the shelf region, although Heald \& Walker (1982) provided some data from the upper continental slope to a depth of about $600 \mathrm{~m}$. The former USSR made 12 cruises in western Australian waters between 1962 and 1974 (E. Nosov, TINRO, Vladivostok, Russia, pers. comm.), but little of the data from those studies have been published.

In this paper, the composition of the western Australian slope fish fauna, its patterns of diversity, density and its spatial structure are described and compared with those of slope regions off southeastern Australia, and with the North Atlantic and northern Pacific Oceans. These faunal characteristics are also discussed in relation to the ocean currents adjacent to the western slope region. Separate papers provide a checklist of the 388 fishes from 109 families collected during the survey with an overview of the fauna (Williams et al. 1996), and a detailed taxonomic account of the grenadiers (Macrouridae and Bathygadidae) that dominate the slope fauna (Iwamoto \& Williams 1999).

\section{MATERIALS AND METHODS}

Sampling strategy. The study area extended between latitudes $20^{\circ}$ and $35^{\circ} \mathrm{S}$ off the western coast of Australia; it was bounded in the north by the $114^{\circ} \mathrm{E}$ meridian (North West Cape), in the south by the $115^{\circ} 08^{\prime}$ E meridian (Cape Leeuwin), and by the 200 and $\sim 1500 \mathrm{~m}$ isobaths (Fig. 1). Samples were collected in 1991 during a 30 d demersal trawling survey by a research vessel (FRV 'Southern Surveyor'), and between 1989 and 1991 during commercial fishing operations. Random-stratified samples $(n=65)$ were taken during the survey from 6 depth strata at $200 \mathrm{~m}$ increments between $200 \mathrm{~m}$ and $1400 \mathrm{~m}$ within 8 latitudinal strata of 100 nautical miles each (1 trawl extended to about $1500 \mathrm{~m}$ depth over steeply sloping bottom). Targeted trawls (directed at fish schools detected by echosounder) were made during the survey $(\mathrm{n}=21)$ and by commercial vessels $(n=56)$. Although the sampling density was low overall, with zero or only 1 randomstratified trawl in some depth/latitude cells, samples were well dispersed over this range of depth and latitude.

The Engels High Lift commercial trawl used in the survey was described by May \& Blaber (1989). This net has a headline length of $35.5 \mathrm{~m}$, headline height of 3.5

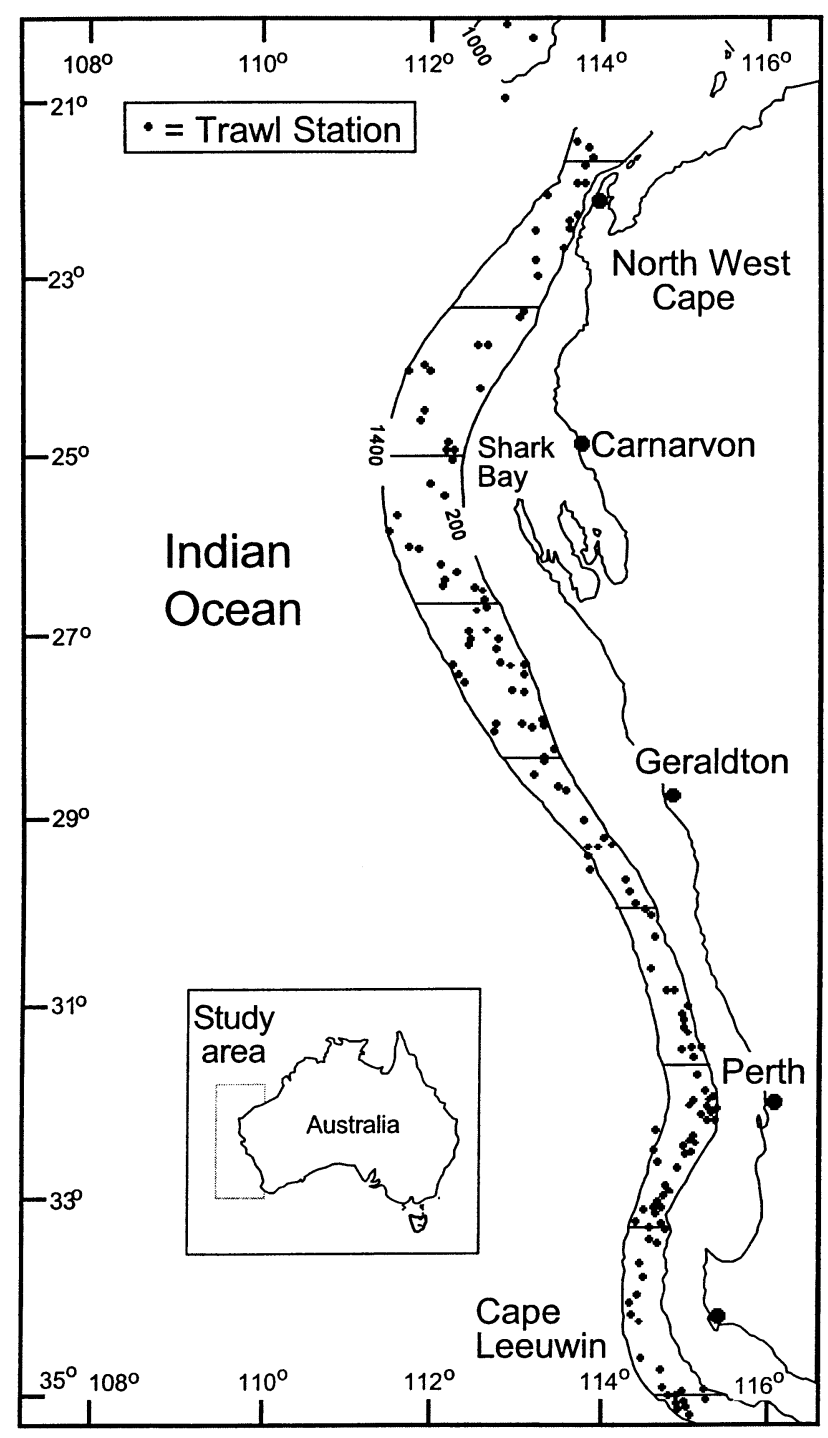

Fig. 1. Study area, showing the distribution of trawl stations, 200 and $1400 \mathrm{~m}$ isobaths, and latitudinal boundaries of strata $\left(21^{\circ} 40^{\prime}, 23^{\circ} 20^{\prime}, 25^{\circ} 00^{\prime}, 26^{\circ} 40^{\prime}, 28^{\circ} 20^{\prime}, 30^{\circ} 00^{\prime}, 31^{\circ} 40^{\prime}, 33^{\circ} 20^{\prime}\right.$, and $35^{\circ} 00^{\prime} \mathrm{S}$ )

to $4 \mathrm{~m}$, wingspread of $19 \mathrm{~m}$, and was fished with a $40 \mathrm{~mm}$ liner in the cod-end, and heavy rubber-bobbin ground gear. It was towed with $50 \mathrm{~m}$ bridles and Polyvalent trawl doors from twin warps. Scanmar transducers were used to monitor net geometry and trawl door spread for all trawls made in depths of less than $1200 \mathrm{~m}$. A Furuno FNR 700 net recorder was used to monitor headline height in deeper water, but no trawl door transducers were used. The commercial trawlers used a variety of large demersal nets and net monitors deployed from twin warps.

Data standardisation and analysis. The numbers and weights of all species were recorded from each survey trawl. Of almost 90000 fishes caught during the 
survey, about 25000 were taken in the 65 randomstratified trawls. The sizes of the 56 commercial catches were not measured, but they were typically larger than the random survey trawls because they targeted fish aggregations. Overall, about $90 \%$ of all fish species recorded were caught during the survey.

Our data were separated into 2 groups for analysis: (1) the 65 random-stratified survey trawls were used to investigate species composition, patterns of diversity, density and community structure; (2) all 151 trawls (i.e. 65 random-stratified survey trawls, 21 targeted survey trawls, 9 survey trawls that were aborted but still caught fish, and 56 targeted commercial trawls) were used to determine the diversity and distributions of species.

Only demersal fishes were sampled quantitatively, so 138 species reported in the literature as epi-, mesoor bathypelagic were excluded from all analyses. These included Serrivomidae, Nemichthyidae, Eurypharyngidae, Bathylagidae, Opisthoproctidae, Gonostomatidae, Sternoptychidae, Astronesthidae, Melanostomiidae, Malacosteidae, Chauliodontidae, Stomiidae, Idiacanthidae, Myctophidae, Notosudidae, Paralepididae, Omosudidae, Alepisauridae, Evermannellidae, Scopelarchidae, Ogcocephalidae (Coelophrys spp.), Ceratoidea, Macrouridae (the genera Hymenocephalus, Mesobius, Squalogadus), Melamphaeidae, Anoplogastridae, Carangidae, Chiasmodontidae, Gempylidae (genera Lepidocybium, Ruvettus, Thyrsitoides), Trichiuridae, Stromateidae (Psenopsis spp.) and Nomeidae. A few unassignable species were retained if they were taken frequently and in appreciable numbers. These included Polymetme corythaeola (Phosichthyidae), Neoscopelus species (Neoscopelidae), Bathyclupea sp. A (Bathyclupeidae), and several species of the family Alepocephalidae.

To estimate fish density, catches were standardised to a total weight of fishes ( $\mathrm{g}$ ) caught over the net-swept area of bottom $\left(\mathrm{m}^{2}\right)$ based on trawl speed $\times$ trawl duration (time of net on bottom) $\times$ estimated wing spread of net. Catchability $(q)$ was assumed to equal 1 because we had no information on gear selectivity. High-density values from the 200 to $400 \mathrm{~m}$ stratum were attributable to large catches taken in 200 to $300 \mathrm{~m}$, so in order to make comparisons with other studies that sampled below $300 \mathrm{~m}$, our shallowest stratum was omitted.

Fish-density data were analysed with a factorial analysis of variance (ANOVA) model based on depth and latitude; depth was partitioned into shelf-break and deeper components, and latitude into single degree of freedom polynomial components. Data were log-transformed to achieve equality of variance. The model fitted addressed an imbalance of sample distribution across the depth $\times$ latitude strata $(59$ samples in
40 cells) by using adjusted least-square means, backtransformed from log to original scale and corrected for bias with $0.5 \mathrm{~s}^{2}$ (the error mean square from ANOVA). Our model also accounted for 2 missing cells (strata with no samples) with a partial test of the depth $\times$ latitude interaction. To appropriately allow for the imbalance, Type II style sums of squares were used for the main effects and depth $\times$ latitude interaction (namely, testing the depth effect after fitting latitude, the latitude effect after fitting depth, and the interaction effect after fitting depth and latitude). Sequential, or Type I style, sums of squares were used for the partitions within each of the main effects. The significance of differences associated with depth and latitude was assessed with Fisher's protected least-significant difference (Steel \& Torrie 1981) and Tukey's procedures for multiple-comparison testing (Zar 1996). A test for trend in density with latitude, possible because of the sequential and regular form of the latitude strata, was based on latitude partitioned into its linear, quadratic and higher-order polynomial components.

Three methods were used to examine community structure in the slope fish fauna:

Method 1: Multispecies distribution patterns were analysed using numerical abundance data in the 'Cluster' and 'MDS' procedures in the PRIMER software package (Carr 1996) to examine the relationships between samples (trawl stations) (Q-mode analysis), and between species (R-mode analysis) (Field et al. 1982). Classification (hierarchical agglomerative and unweighted arithmetic average clustering) and ordination (non-metric multidimensional scaling) were based on the non-metric Bray-Curtis 'percent difference' measure (Legendre \& Legendre 1998). Abundance data were transformed prior to analysis using $\log _{10}(n+1)$. Partial redundancy analysis in the CANOCO software package (ter Braak \& Smilauer 1998) was used to test the influence of environmental variables on distribution patterns. This technique partitions the multivariate variability attributable to predictor variables and tests the significance of canonical axes by permutation (Monte Carlo) testing. Data for R-mode analysis were first standardised by transforming the raw numerical abundance score for each species into a percentage of the total score for that species over all stations (Field et al. 1982). Analyses were based on species that were numerically dominant at 1 or more stations, rather than the most-abundant species overall (pooled stations); cut-off points at 5 and $15 \%$ dominance retained suitable numbers of species for each analysis - 103 species for Q-mode and 55 species for R-mode, respectively.

Method 2: Because less abundant species with restricted biocenotic distributions can also characterise fish communities, the frequencies of species occurrences were analysed for each cluster of stations 
formed by classification analysis to identify indicator species. Forty-two species that were largely restricted to 1 cluster ( $\geq 65 \%$ of total occurrences) and occurred at most of the stations comprising a cluster $(\geq 50 \%)$ were designated as indicator species. The distributions and provincial association of indicator species was assessed with reference to Smith \& Heemstra (1986), Paxton et al. (1989), Gomon et al. (1994), Last \& Stevens (1994), Duhamel (1995) and Williams et al. (1996).

Method 3: The latitudinal continuity of slope communities was assessed by comparing species overlap from 4 mid-slope zones (>700 m: $20-22^{\circ} \mathrm{S}, 22-27^{\circ} \mathrm{S}$, $27-32^{\circ} \mathrm{S}, 32-35^{\circ} \mathrm{S}$ ) and 2 upper-slope zones (300 to $700 \mathrm{~m}: 22-27^{\circ} \mathrm{S}, 27-35^{\circ} \mathrm{S}$ ) off western Australia with, respectively, the southeastern mid-slope (800 to $1200 \mathrm{~m}$ ) (Koslow et al. 1994) and upper-slope (350 to $500 \mathrm{~m}$ ) (May \& Blaber 1989). To obtain a measure that reflected the influence of dominant species, we also computed the overlap of species represented in more than one-third of the southeastern Australian samples. Measurement of community overlap was based upon Sorenson's coefficient of community, $S$ (Legendre \& Legendre 1998):

$$
S=\frac{200 \cdot C}{A+B}
$$

where $A$ and $B$ are the total number of taxa in the 2 regions being compared and $C$ is the number in common.

Our raw data are archived at the CSIRO Marine Laboratories in Hobart and are available separately. Contact should be through the senior author (A.W.).

Taxonomic identifications. Collections of voucher specimens were lodged with 4 Australian ichthyological collections (Australian Museum, Sydney; I.S.R. Munro Ichthyological Collection, CSIRO Marine Laboratories, Hobart; Museum of Victoria, Melbourne; Western Australian Museum, Perth). Williams et al. (1996) presented a species checklist with horizontal and vertical limits of distribution and voucher specimen registration numbers.

\section{RESULTS}

\section{Faunal diversity}

Of the 388 fishes in 109 families obtained in this study (Williams et al. 1996), 310 species in 90 families were taken in the 65 random-stratified samples from the research vessel survey (Table 1). The remaining species were from targeted and aborted survey trawls (31 species from 6 families) or commercial catches (47 species from 13 families).
Table 1. Number of species of demersal fishes recorded by family in 65 random-stratified trawls from the continental slope off the west coast of Australia. (A full checklist of species is presented by Williams et al. 1996). n: number of species

\begin{tabular}{|c|c|c|c|}
\hline Family & $\mathrm{n}$ & Family & $\mathrm{n}$ \\
\hline Hexanchidae & 1 & Macrourocyttidae & 1 \\
\hline Scyliorhinidae & 8 & Zeidae & 6 \\
\hline Triakidae & 3 & Grammicolepididae & 2 \\
\hline Squalidae & 20 & Oreosomatidae & 3 \\
\hline Pristiophoridae & 1 & Caproidae & 2 \\
\hline Squatinidae & 2 & Macroramphosidae & 3 \\
\hline Narcinidae & 2 & Scorpaenidae & 9 \\
\hline Rajidae & 8 & Triglidae & 11 \\
\hline Anacanthobatidae & 2 & Platycephalidae & 3 \\
\hline Hexatrygonidae & 1 & Hoplichthyidae & 3 \\
\hline Urolophidae & 3 & Ereuniidae & 1 \\
\hline Myliobatidae & 1 & Psychrolutidae & 1 \\
\hline Chimaeridae & 4 & Cyclopteridae & 1 \\
\hline Rhinochimaeridae & 1 & Serranidae & 4 \\
\hline Nettastomatidae & 3 & Priacanthidae & 3 \\
\hline Congridae & 4 & Acropomatidae & 7 \\
\hline Colocongridae & 1 & Epigonidae & 3 \\
\hline Synaphobranchidae & 4 & Malacanthidae & 1 \\
\hline Halosauridae & 4 & Nemipteridae & 2 \\
\hline Notacanthidae & 1 & Sparidae & 1 \\
\hline Argentinidae & 1 & Mullidae & 1 \\
\hline Alepocephalidae & 17 & Bathyclupeidae & 1 \\
\hline Leptochilichthyidae & 1 & Pentacerotidae & 2 \\
\hline Platytroctidae & 2 & Oplegnathidae & 1 \\
\hline Phosichthyidae & 1 & Cheilodactylidae & 2 \\
\hline Ateleopodidae & 1 & Cepolidae & 1 \\
\hline Chlorophthalmidae & 5 & Sphyraenidae & 1 \\
\hline Ipnopidae & 3 & Pinguipedidae & 2 \\
\hline Synodontidae & 4 & Percophidae & 1 \\
\hline Neoscopelidae & 2 & Uranoscopidae & 3 \\
\hline Barbourisiidae & 1 & Champsodontidae & 2 \\
\hline Polymixiidae & 2 & Callionymidae & 1 \\
\hline Moridae & 7 & Gempylidae & 4 \\
\hline Ophidiidae & 13 & Centrolophidae & 1 \\
\hline Bythitidae & 1 & Nomeidae & 2 \\
\hline Carapidae & 1 & Ariommatidae & 1 \\
\hline Bathygadidae & 3 & Citharidae & 1 \\
\hline Macrouridae & 41 & Bothidae & 2 \\
\hline Lophidae & 3 & Paralichthyidae & 1 \\
\hline Chaunacidae & 4 & Pleuronectidae & 2 \\
\hline Ogcocephalidae & 5 & Triacanthodidae & 4 \\
\hline Diretmidae & 2 & Monacanthidae & 1 \\
\hline Trachichthyidae & 4 & Ostraciidae & 2 \\
\hline Berycidae & 2 & Tetraodontidae & 2 \\
\hline Holocentridae & 1 & & \\
\hline \multirow[t]{2}{*}{ Parazenidae } & 1 & Total families & 90 \\
\hline & & Total species & 310 \\
\hline
\end{tabular}

Species accumulation from the random-stratified catches (Fig. 2A) showed that about $50 \%$ of fishes were obtained in the first 13 trawls and that the accumulation rate decreased noticeably after about 30 trawls; species accumulation did not reach an asymptote, indicating that additional species would be caught with further sampling. The fauna is characterised by high diversity: in our samples most species 

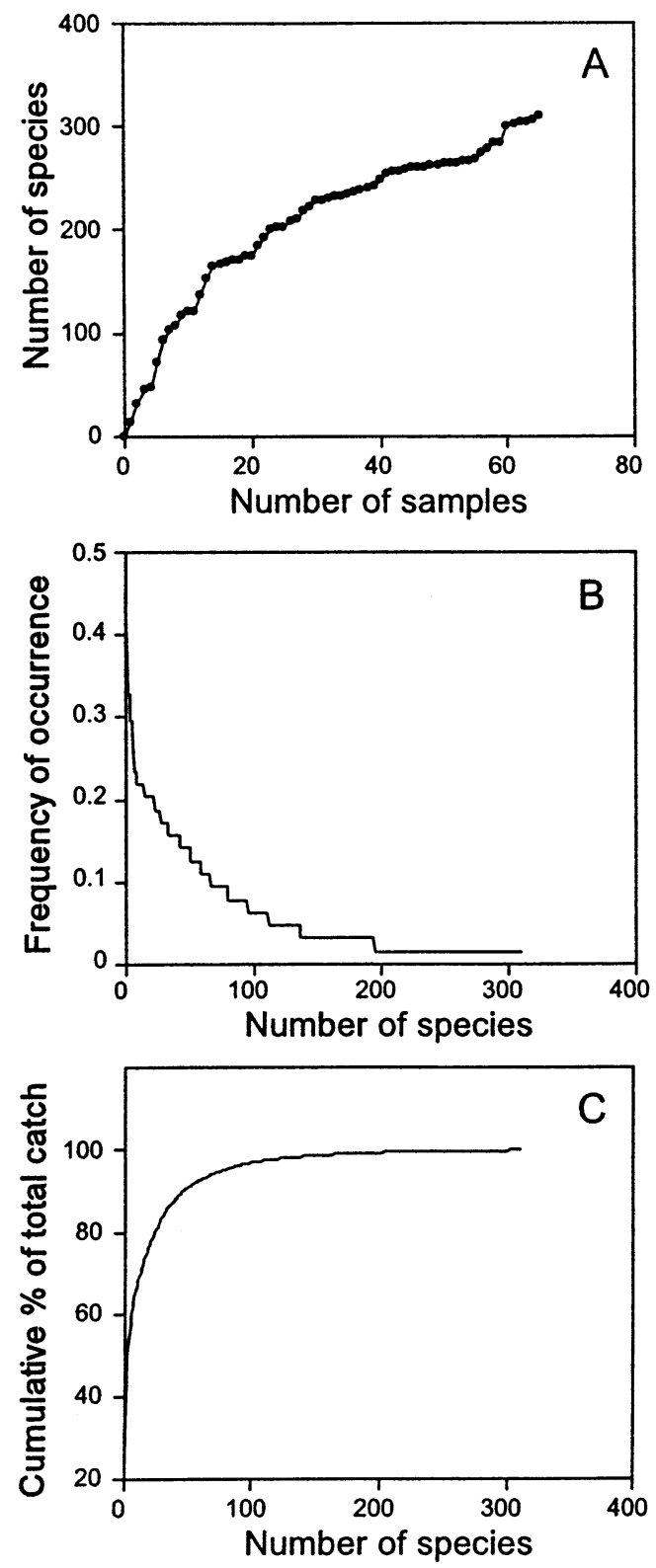

Fig. 2. Data from the 65 random-stratified survey stations showing: (A) cumulative number of species caught as a function of the number of trawl samples taken (ordered from north to south); (B) distribution of the frequency of occurrence of species; (C) cumulative percentage of the total catch (in numbers of individuals) by species, ranked in order of abundance

occurred infrequently (Fig. 2B) with 173 species (about $56 \%$ ) present in only 1 or 2 samples; 34 families (about $38 \%$ ) were represented by single species (Table 1). Only 14 species each contributed more than $1 \%$ of total numbers, while 25 species collectively made up $80 \%$ of total numbers (Fig. 2C).

The 5 dominant families (based on numerical abundance) in each of the 6 depth strata are shown in Fig. 3.
Samples from the 2 shallowest strata (200 to 399 and 400 to $599 \mathrm{~m}$ depths) were dominated principally by the Acropomatidae and Chlorophthalmidae, with grenadiers, Macrouridae and Bathygadidae, the most abundant families in greater depths (600 to $1400 \mathrm{~m}$ ). The Synaphobranchidae, Alepocephalidae and Oreosomatidae were also among the dominant families in more than 1 stratum below $800 \mathrm{~m}$ depth. As well as being among the most abundant families in 5 of the 6 depth strata, the Macrouridae is also the most speciesrich family (Table 1).

\section{Density}

Standardised catch data, stratified by depth and latitude, showed that the density of demersal fishes on the western Australian slope was low (Table 2A). Density estimates exceeded $1 \mathrm{~g} \mathrm{~m}^{-2}$ in the shallowest (shelfbreak) stratum (200 to $399 \mathrm{~m}$ ), except from a single small catch between Latitudes $30^{\circ} 00^{\prime}$ and $31^{\circ} 40^{\prime} \mathrm{S}$ (Table 2A). In all deeper strata, fish density was less than $1 \mathrm{~g} \mathrm{~m}^{-2}$.

ANOVA showed that density varied significantly with depth $(p<0.001)$ and latitude $(p=0.011)$ (Table 2B). The

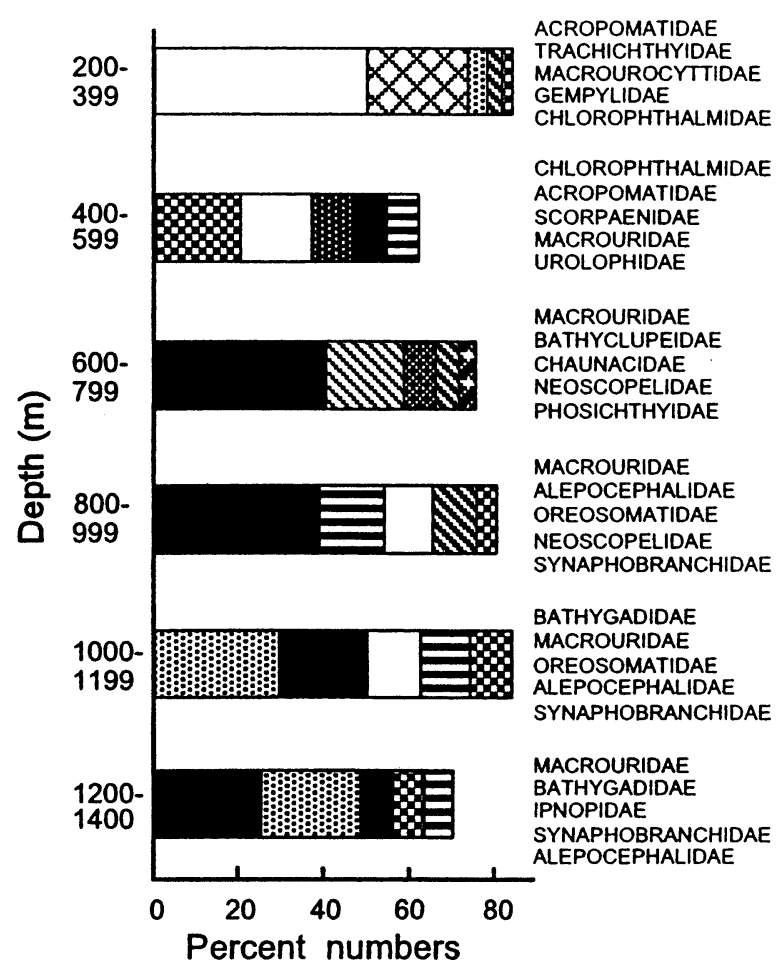

Fig. 3. Dominant 5 families (ranked by percentage numbers) in each of the 6 depth strata from the 65 random-stratified survey stations. For each stratum, families are listed in order of decreasing abundance 
complete depth $\times$ latitude interaction term with $28 \mathrm{df}$ could not be fully tested because there were no data for 2 of the depth $\times$ latitude cells. However, a partial test based on the 26 available degrees of freedom component indicated no significant interaction $(F=1.182$, df $=26, \mathrm{p}=0.351)$ (Table 2B). As it was unlikely that observations for the other 2 cells would have changed this result, subsequent analyses assumed no interaction. With the interaction effect removed, the significance of the main effects were: depth $(F=10.75, \mathrm{df}=4$, $\mathrm{p}<0.001)$ and latitude $(F=3.25$, $\mathrm{df}=7, \mathrm{p}=0.007$ ).

The significant depth effect (4 df) was attributable only to a difference between the shelf-break (200 to $399 \mathrm{~m}$ stratum) and slope (strata deeper than $400 \mathrm{~m})(\mathrm{p}<0.001)$. No difference was detected between the 4 deeper slope strata $(p=0.294)$. Multiple-comparison tests between all 5 depth strata were consistent with this result.

Density was lowest at northern latitudes and increased significantly with increasing latitude in a linear manner, since when latitude was partitioned into polynomial components only the linear component was significant $(p=0.001)$ in the ANOVA (Table 2B).
Table 2. (A) Estimated demersal fish biomass $\left(\mathrm{g} \mathrm{m}^{-2}\right)$ by latitude and depth strata. Depth/ latitude cells show means of raw data and the corresponding means for each depth and latitude stratum. Ad. $\bar{X}$ : adjusted mean, i.e. the least-square mean, backtransformed from log to original scale and corrected for bias by $0.5 \mathrm{~s}^{2}$ (error mean square from ANOVA table below). $\mathrm{n}$ : total number of samples per stratum; depths 1 to 5 are five $200 \mathrm{~m}$ strata $(200-399,400-599,600-799,800-999,1000-1200)$; latitude boundaries 1 to 8 are shown in Fig. 1. (B) Analysis of variance table for the factors 'depth', 'latitude', their partitions and interaction term

\begin{tabular}{|c|c|c|c|c|c|c|c|c|c|}
\hline \multicolumn{10}{|c|}{ (A) Fish biomass $\left(\mathrm{g} \mathrm{m}^{-2}\right.$ ) } \\
\hline \multirow[t]{2}{*}{ Latitude } & \multicolumn{5}{|c|}{ —Depth } & \multirow[t]{2}{*}{$\mathrm{n}$} & \multirow{2}{*}{$\begin{array}{c}\bar{X} \\
1-5\end{array}$} & \multirow{2}{*}{$\begin{array}{c}\bar{X} \\
2-5\end{array}$} & \multirow{2}{*}{$\begin{array}{r}\text { Ad. } \bar{X} \\
1-5\end{array}$} \\
\hline & 1 & 2 & 3 & 4 & 5 & & & & \\
\hline 1 & 1.28 & 0.19 & 0.07 & 0.25 & 0.14 & 10 & 0.39 & 0.16 & 0.26 \\
\hline 2 & 3.14 & 0.46 & 0.23 & 0.16 & 0.40 & 9 & 0.88 & 0.31 & 0.59 \\
\hline 3 & 1.02 & 0.83 & 0.22 & 0.31 & 0.36 & 6 & 0.55 & 0.43 & 0.58 \\
\hline 4 & 1.19 & 0.42 & 0.31 & 0.68 & 0.31 & 10 & 0.58 & 0.43 & 0.54 \\
\hline 5 & 4.03 & 0.99 & 0.13 & 0.75 & 0.65 & 5 & 1.31 & 0.63 & 0.97 \\
\hline 6 & 0.32 & 0.66 & 0.21 & 0.73 & 0.14 & 6 & 0.41 & 0.44 & 0.46 \\
\hline 7 & 2.37 & 0.44 & 0.77 & 0.94 & 0.74 & 8 & 1.05 & 0.72 & 0.92 \\
\hline 8 & 3.21 & - & 0.87 & 0.62 & - & 5 & 1.57 & 0.75 & 1.01 \\
\hline $\mathrm{n}$ & 12 & 11 & 10 & 15 & 11 & 59 & & & \\
\hline $\bar{X}$ & 2.07 & 0.57 & 0.35 & 0.56 & 0.39 & & & & \\
\hline Ad. $\bar{X}$ & 1.94 & 0.59 & 0.34 & 0.51 & 0.44 & & & & \\
\hline \multicolumn{10}{|c|}{ (B) ANOVA } \\
\hline Source & & & df & & SS & MS & $F$ & & $\mathrm{p}$ \\
\hline Depth & & & 4 & & 21.092 & 5.273 & \multicolumn{2}{|l|}{11.289} & 0.000 \\
\hline \multirow{2}{*}{\multicolumn{3}{|c|}{$\begin{array}{l}\text { Depth } 1 \text { vs Depths 2-5 } \\
\text { Between Depths 2-5 }\end{array}$}} & 1 & & 19.325 & 19.325 & \multicolumn{2}{|l|}{43.354} & 0.000 \\
\hline & & & 3 & & 1.767 & 0.589 & 1.321 & & 0.294 \\
\hline \multicolumn{3}{|l|}{ Latitude } & 7 & & 11.161 & 11.161 & \multicolumn{2}{|l|}{3.577} & 0.011 \\
\hline \multirow{2}{*}{\multicolumn{3}{|c|}{$\begin{array}{l}\text { Linear component } \\
\text { Deviations from linear }\end{array}$}} & 1 & & 6.413 & 6.413 & \multicolumn{2}{|l|}{13.073} & 0.001 \\
\hline & & & 6 & & 4.748 & 0.791 & 1.613 & & 0.164 \\
\hline \multicolumn{3}{|c|}{ Depth $\times$ Latitude } & 26 & & 13.694 & 0.527 & \multicolumn{2}{|l|}{1.182} & 0.351 \\
\hline \multicolumn{3}{|l|}{ Error } & 21 & & 9.361 & 0.446 & & & \\
\hline \multicolumn{3}{|l|}{ Total } & 58 & & 55.374 & & & & \\
\hline
\end{tabular}

\section{Community structure}

A classification of random survey station data (Q-mode analysis) identified 7 primary communities (Clusters 1 to 7 ) within 2 main groups at the 0.65 level of similarity (Fig. 4). Ordination of data showed good correspondence with clusters, with the 65 samples being adequately represented (stress $=0.17$ ) in 2-dimensional space (Fig. 5A). Groupings appeared to be strongly influenced by depth and latitude, and this was confirmed by superimposing their values on the ordination plot (Fig. 5B and C respectively). A test of this hypothesis (that multispecies spatial distributions were structured by depth and latitude) using partial redundancy analysis showed there were very strong correlations between depth and the first canonical axis $\left(\mathrm{r}^{2}=0.845\right)$, and between latitude and the second axis $\left(r^{2}=0.803\right)$. The percentages of total variance explained by the 2 variables
(0.389) on the first and second axes were 77 and $23 \%$; permutation tests (500 runs) for canonical axes were all highly significant $(p=0.002)$. A plot of samples against depth and latitude (Fig. 5D) showed that sample groupings delineated shelf-break/upper-slope communities (Clusters 1 to 4 ) and mid-slope communities (Clusters 5 to 7 ) at a boundary near the $700 \mathrm{~m}$ isobath.

In the shelf-break/upper-slope group, stations in Clusters 1 and 2 defined communities from a shelfbreak community $(\sim 200$ to $400 \mathrm{~m})$ at southern and northern latitudes ( $\sim 28$ to 34 and $\sim 22$ to $27^{\circ} \mathrm{S}$ respectively); Clusters 3 and 4 delineated 2 communities from the shallow and deep upper-slope at depths of $\sim 350$ to 500 and $\sim 500$ to $700 \mathrm{~m}$ respectively. Stations in Cluster 3 could be further subdivided into 2 sub-clusters, 3A and $3 \mathrm{~B}$, corresponding to suites of fishes from southern and northern latitudes $\left(\sim 27\right.$ to 33 and $\sim 24$ to $27^{\circ} \mathrm{S}$ respectively). 
In the mid-slope group, stations in Clusters 5 and 6 defined communities from a shallow mid-slope community ( 700 to $950 \mathrm{~m})$, while Cluster 7 delineated a deep mid-slope community ( 900 to $1300 \mathrm{~m})$. Clusters 6 and 7 could also both be further partitioned into sub-clusters based on latitude: the northern shallow mid-slope stations to Subclusters $6 \mathrm{~A}\left(\sim 20\right.$ to $\left.26^{\circ} \mathrm{S}\right)$ and $6 \mathrm{~B}$ $\left(\sim 27\right.$ to $\left.31^{\circ} \mathrm{S}\right)$ and the deep mid-slope stations to Subclusters $7 \mathrm{~A}\left(\sim 24\right.$ to $\left.34^{\circ} \mathrm{S}\right)$ and $7 \mathrm{~B}\left(\sim 20\right.$ to $\left.22^{\circ} \mathrm{S}\right)$.

A classification based on species data (R-mode analysis) delineated 6 clusters in 2 main community-level groups at the 0.55 level of similarity (Fig. 6). These groups delineated species from shelf-break/ upper-slope and mid-slope communities and corresponded with the main groups defined by Q-mode analysis. Once again, 4 clusters were formed by shelf-break/ upper-slope species based on depth and latitude: southern shelf-break species (Cluster 1), northern shelf-break species (Cluster 2), shallow upperslope species (Cluster 3), and deep upper-slope species (Cluster 4). Midslope species formed 2 clusters: Cluster 5 containing southern, shallow midslope species and Cluster 6 the remaining mid-slope species. In contrast to the result of $\mathrm{Q}$-mode analysis, a northern, shallow mid-slope community was not clearly delineated from deep mid-slope species.

The 6 species comprising Cluster 1 (Fig. 6) characterise a southern community of the well-defined shelf-break community. This community occurs in $\sim 200$ to $400 \mathrm{~m}$ and extends northwards from the southern limit of the study area to about $28^{\circ} \mathrm{S}$ latitude (Fig. 5D). Indicator species (Table 3) from the corresponding station group were Squatina tergocellata, Urolophus expansus, Neoplatycephalus conatus and Kathetostoma nigrofasciatum, which are typically Flindersian in distribution (western warm temperate Australia), and Pristiophorus cirratus and Pterygotrigla polyommata, which are more widespread off southern Australia on the outer continental shelf and upper-

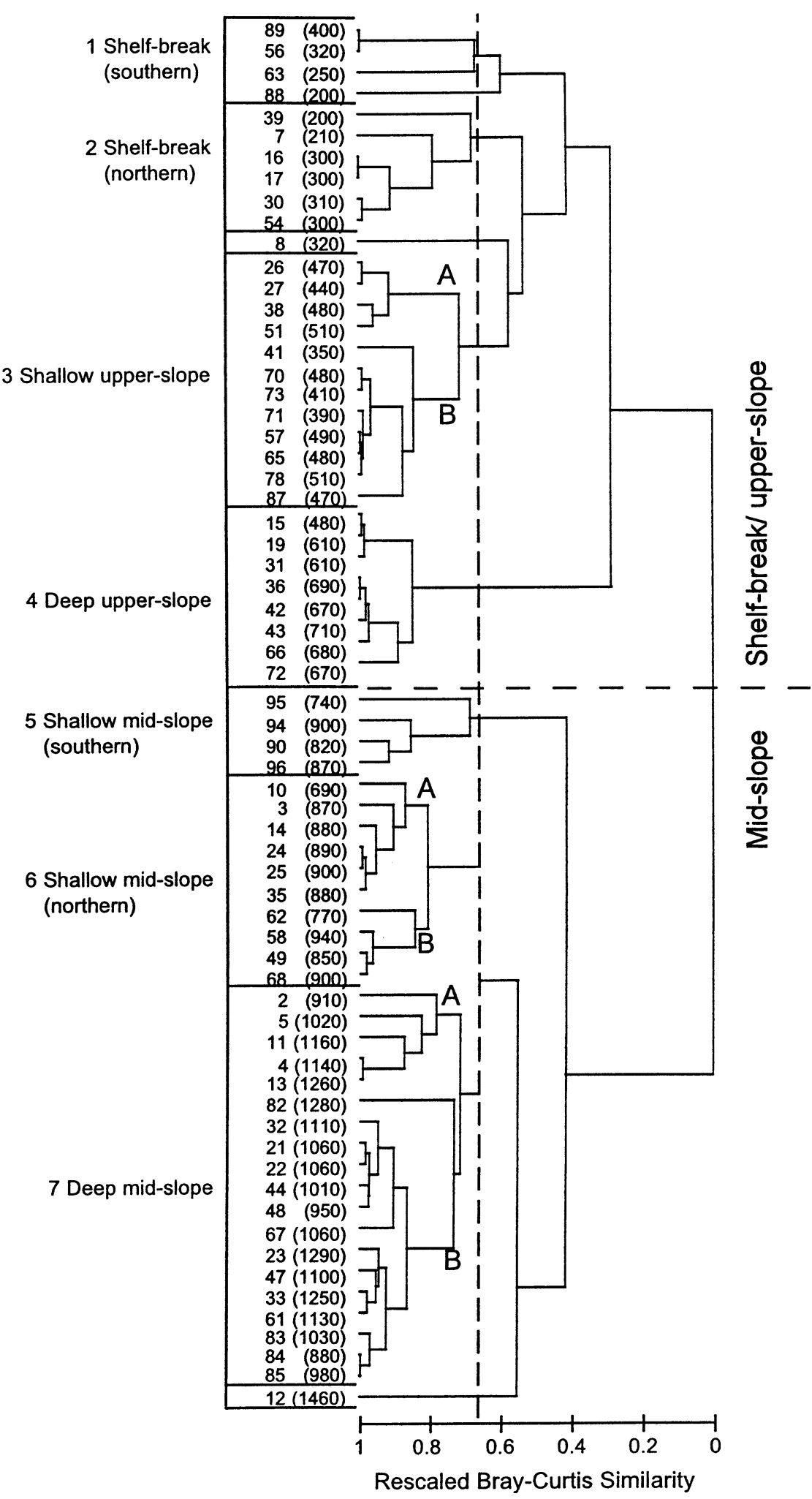

Fig. 4. Q-mode classification of 65 random-stratified survey trawl stations by hierarchical agglomerative clustering using unweighted arithmetic averages. Clusters (1 to 7 ) are based upon an arbitrary level of similarity of 0.65 (A and $\mathrm{B}=2$ main groups). Trawl station numbers are shown together with their mean depth $(\mathrm{m})$ in parentheses 

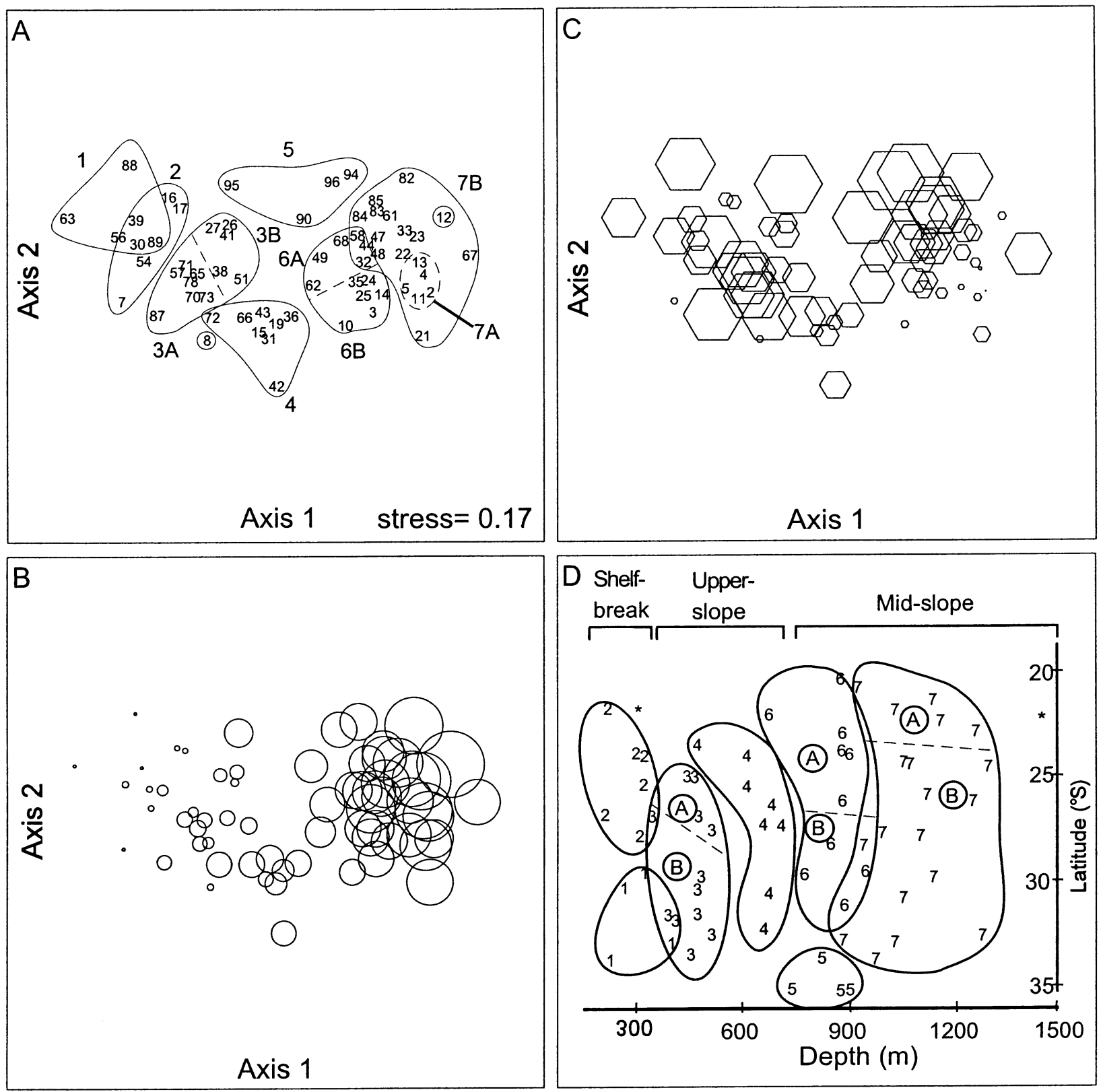

Fig. 5. Representation of the 65 random-stratified survey trawl stations in (A) 2-dimenional ordination space based on non-metric multidimensional scaling (station numbers shown and groups labelled according to clusters in Fig. 4); (B) depth values superimposed on ordination plot (circle diameter scaled with increasing depth); (C) latitude values superimposed on ordination plot (hexagon size scaled with increasing latitude); (D) depth-latitude zones formed by the 65 random-stratified survey trawl stations where numbers and groups correspond to clusters formed by Q-mode analysis (Fig. 4). ${ }^{*}$ Unclustered stations

slope. Many of the other species caught within this zone are temperate elements that also extend well eastward of southern Australia and occur both on the outer shelf and upper-slope.

A northern community of shelf-break species was represented by 6 species in Cluster 2 (Fig. 6); this community occurred in a similar depth range to the southern shelf-break community ( 200 to $300 \mathrm{~m}$ ) but ranged from the northern limit of sampling south to about $27^{\circ} \mathrm{S}$ (Fig. 5). Indicator species (Table 3) were Citharoides macrolepidotus, known from the northwestern Pacific, and 4 undescribed taxa: Squalus sp. D, Chlorophthalmus sp. B, and Lepidotrigla species A and B, that are endemic to western central and northwestern Australia. These species co-occurred with numerous tropical fishes that extend southwards from northwestern Australia. 
Table 3. Indicator species from depth/latitude zones on the western Australian continental slope defined by cluster analysis of stations (Fig. 4). The degree of restriction and occurrence within the zone is shown for each indicator species

\begin{tabular}{|c|c|c|c|c|c|c|}
\hline $\begin{array}{l}\text { Station } \\
\text { Cluster }\end{array}$ & $\begin{array}{l}\text { No. of stations } \\
\text { in cluster }\end{array}$ & $\begin{array}{l}\text { Total no. } \\
\text { of species }\end{array}$ & Zone & Indicator species & $\begin{array}{l}\text { o restriction } \\
\text { to zone }\end{array}$ & $\begin{array}{l}\% \text { occurrence } \\
\text { in zone }\end{array}$ \\
\hline 1 & 4 & 46 & Southern shelf-break & $\begin{array}{l}\text { Pristiophorus cirratus } \\
\text { Squatina tergocellata } \\
\text { Urolophus expansus } \\
\text { Pterygotrigla polyommata } \\
\text { Neoplatycephalus conatus } \\
\text { Kathetostoma nigrofasciatum }\end{array}$ & $\begin{array}{r}100 \\
80 \\
100 \\
100 \\
100 \\
100\end{array}$ & $\begin{array}{r}50 \\
100 \\
50 \\
75 \\
75 \\
50\end{array}$ \\
\hline 2 & 6 & 86 & Northern shelf-break & $\begin{array}{l}\text { Squalus sp. D } \\
\text { Chlorophthalmus sp. B } \\
\text { Lepidotrigla sp. A } \\
\text { Lepidotrigla sp. B } \\
\text { Citharoides macrolepidotus }\end{array}$ & $\begin{array}{r}80 \\
83 \\
80 \\
71 \\
100\end{array}$ & $\begin{array}{l}67 \\
83 \\
67 \\
83 \\
50\end{array}$ \\
\hline 3 & 12 & 83 & Shallow upper-slope & $\begin{array}{l}\text { Squalus mitsukurii } \\
\text { Chlorophthalmus sp. C } \\
\text { Euclichthys polynemus } \\
\text { Caelorinchus mirus } \\
\text { Hoplostethus latus } \\
\text { Notopogon xenosoma } \\
\text { Helicolenus barathri } \\
\text { Apogonops anomolus }\end{array}$ & $\begin{array}{r}67 \\
70 \\
92 \\
78 \\
100 \\
70 \\
69 \\
82\end{array}$ & $\begin{array}{l}67 \\
58 \\
92 \\
58 \\
83 \\
58 \\
75 \\
75\end{array}$ \\
\hline 4 & 8 & 59 & Deep upper-slope & $\begin{array}{l}\text { Neoscopelus sp. A } \\
\text { Caelorinchus charius } \\
\text { Malacocephalus laevis } \\
\text { Ventrifossa sazonovi } \\
\text { Bathyclupea sp. A }\end{array}$ & $\begin{array}{r}80 \\
78 \\
65 \\
80 \\
100\end{array}$ & $\begin{array}{r}50 \\
88 \\
100 \\
50 \\
100\end{array}$ \\
\hline 5 & 4 & 32 & $\begin{array}{l}\text { Southern shallow } \\
\text { mid-slope }\end{array}$ & $\begin{array}{l}\text { Deania calcea } \\
\text { Etmopterus lucifer } \\
\text { Mora moro } \\
\text { Neocyttus rhomboidalis } \\
\text { Trachyscorpia capensis }\end{array}$ & $\begin{array}{r}80 \\
100 \\
100 \\
100 \\
100\end{array}$ & $\begin{array}{r}100 \\
50 \\
50 \\
50 \\
50\end{array}$ \\
\hline 6 & 10 & 77 & $\begin{array}{l}\text { Northern shallow } \\
\text { mid-slope }\end{array}$ & $\begin{array}{l}\text { Rouleina guentheri } \\
\text { Neoscopelus macrolepidotus } \\
\text { Mataeocephalus acipenserinus }\end{array}$ & $\begin{array}{l}65 \\
77 \\
70\end{array}$ & $\begin{array}{r}80 \\
100 \\
70\end{array}$ \\
\hline 7 & 19 & 102 & Deep mid-slope & $\begin{array}{l}\text { Synaphobranchus brevidorsalis } \\
\text { Narcetes lloydii } \\
\text { Bathypterois ventralis } \\
\text { Bathygadus spongiceps } \\
\text { Nezumia wularnia } \\
\text { Sphagemacrurus pumiliceps } \\
\text { Trachonurus yiwardaus } \\
\text { Scombrolabrax heterolepis }\end{array}$ & $\begin{array}{r}77 \\
100 \\
67 \\
100 \\
68 \\
83 \\
79 \\
83\end{array}$ & $\begin{array}{l}53 \\
53 \\
53 \\
74 \\
79 \\
53 \\
58 \\
53\end{array}$ \\
\hline
\end{tabular}

The 10 species comprising Cluster 3 (Fig. 6) characterise a community from the shallow depth range ( 350 to $500 \mathrm{~m}$ ) of the upper-slope. Indicators in this community (Table 3) were Hoplostethus latus (restricted to this zone and caught at 10 stations); 5 stenobathic, widespread southern Australian temperates Squalus mitsukurii, Euclichthys polynemus, Caelorinchus mirus, Helicolenus barathri and Apogonops anomolous; the undescribed Chlorophthalmus sp. C, which is probably restricted to the region, and Notopogon xenosoma, which is almost circumglobal in the subtropical belt of the Southern Hemisphere. The ranges of other species in this community were consistent with the latitudinal structure evident in sub-groups formed in the Q-mode analysis (Fig. 4), being either tropical elements extending southwards or warm temperate elements extending northwards.

A further 9 species characterise a community from a deeper range on the upper-slope ( 500 to $700 \mathrm{~m})$ (Cluster 4, Fig. 6). Among indicator species (Table 3) Bathyclupea sp. A was caught at all stations and restricted to this zone, while other indicator species were the undescribed western Australian endemics Neoscopelus sp. A and Caelorinchus charius, and more widespread macrourids Malacocephalus laevis (southern Australian temperate) and Ventrifossa sazonovi (Indo- 


\section{Shelf-break} (southern)

2 Shelf-break (northern)

\section{Shallow upper-slope}

4 Deep upper-slope

\section{Deep mid-slope}

5 Shallow mid-slope (southern) stratified survey trawl stations by hierarchical agglomerative clustering using unweighted arithmetic averages. Clusters (1 to 6$)$ are based upon an arbitrary level of similarity of 0.55
West Pacific). All indicator species were distributed over the range of latitude $\left(\sim 22\right.$ to $\left.33^{\circ} \mathrm{S}\right)$ represented by deep upperslope stations (Fig. 5). The remaining species in this zone include many tropical elements extending southwards and warm temperate elements extending northwards.

The 3 species in Cluster 5 (Fig. 6) characterise a southern community of the shallow mid-slope community. This community occurs in $\sim 700$ to $950 \mathrm{~m}$ and extends from the southern limit of the study area north to about $33^{\circ} \mathrm{S}$ latitude (Fig. 5D). The indicator species in this community (Table 3 ) are Deania calcea, Etmopterus lucifer, Moro moro, Neocyttus rhomboidalis and Trachyscorpia capensis. These fishes are geographically widespread, but in Australian waters have stenobathic temperate distributions around the entire southern Australian coast. The remaining species of this community are dominated by widespread species that are either warm temperate or have penetrated the west coast region from the south. Some infrequently occurring benthic species, e.g. skates, appear to be confined to the western Australian slope.

The failure of R-mode analysis to delineate a northern community on the shallow mid-slope from the deep midslope community (Fig. 6) was most likely due to the broad and overlapping bathymetric ranges of the abundant species used in the analysis. Identification of indicator species in the groups of stations from each of these zones (Clusters 6 and 7, Fig. 4) showed that several species were largely restricted to one or other community (Table 3). Three were taken from the 10 northern stations on the shallow upper-slope: Rouleina guentheri, Neoscopelus macrolepidotus and Mataeocephalus acipenserinus. All are widely distributed in tropical and temperate oceanic regions adjacent to Australia, but off western Australia ranged mostly from the deep upper-slope down to $\sim 1000 \mathrm{~m}$.

Eight species from the 19 deep midslope stations met our criteria as indicator species: Synaphobranchus brevidorsalis, Narcetes lloydii, Bathypterois ven- 
tralis, Bathygadus spongiceps, Nezumia wularnia, Sphagemacrurus pumiliceps, Trachonurus yiwardaus and Scombrolabrax heterolepis. They are also widely distributed in tropical and temperate waters but have deeper bathymetric distributions than the shallow, northern mid-slope species and typically extend from $\sim 900 \mathrm{~m}$ to beyond $1500 \mathrm{~m}$ (our limit of sampling), with a centre of abundance below $\sim 1000 \mathrm{~m}$. Thus, in the mid-slope zone, indicator species provided a clearer picture of community structure by depth than more abundant species.

\section{DISCUSSION}

\section{Faunal diversity}

The 388 demersal fishes in 109 families collected during the first survey of the western Australian slope are a substantial component of the known Australian fish fauna. The collection clearly illustrates the comparatively high diversity of the deep-sea component of a fish fauna that is rich in world terms (Paxton et al. 1989 ) in making up about $9 \%$ of the $4100+$ known species (Yearsley et al. 1997) and one-third of about 300 families (Paxton et al. 1989). There is a high likelihood that further sampling off western Australia would reveal additional species, since speciesaccumulation did not reach an asymptote in the survey samples. Small species, as well as benthopelagic and benthic species, may have been undersampled by our large, pairedwarp, trawl rig (e.g. Gordon \& Bergstad 1992). Unpublished data show that small-meshed prawn trawls catch different suites of slope fishes, such as ophidiids and congrids, in adjacent waters off northwestern Australia. We may also have under-sampled large, mobile fishes because species such as the lutjanid Etelis carbunculus occur in considerably greater abundance in commercial trawls that are towed at faster speeds.

Species richness and familylevel diversity off western Australia are high compared to 2 oceanic regions of the North- ern Hemisphere for which broad-scale survey data are available (Table 4). Fewer slope fishes (296 species from 57 families) were taken by more comprehensive surveys of broader latitudinal and bathymetric ranges in the North Atlantic Basin (Haedrich \& Merrett 1988, 1990) - although more recently, Merrett (1994) listed 505 species from the North Atlantic in depths below $200 \mathrm{~m}$ (exclusive of shelf species). The total of 199 slope fishes in 19 families collected from surveys of the northern Pacific Ocean (Pearcy et al. 1982, Dudnik \& Dolganov 1992) was considerably less than taken off western Australia, although low latitudes and the upperslope (200 to $400 \mathrm{~m}$ ) were not sampled in the Pacific (Table 4). Thus, despite their disparate effort and spatial coverage, these surveys indicate that diversity may be exceptionally high in the Australian slope region.

The high diversity of the western Australian slope fauna is attributable to the overlap of rich, independently evolved tropical and temperate faunas. The relatively high proportions of southern temperate Australasian species, tropical species with Indo-Pacific affinities, and western endemics indicates a similar degree of mixing of these faunas to that in shallow western fishes (Hutchins 1994). The structure of modern Australian shallow marine faunas is considered to

Table 4. Comparison of family and species numbers and sampling effort in regional deepwater demersal fish faunas. All depths: continental slope, continental rise and abyssal depths combined

\begin{tabular}{|c|c|c|c|c|c|c|}
\hline $\begin{array}{l}\text { Geographical } \\
\text { region }\end{array}$ & $\begin{array}{l}\text { Depth } \\
\text { range } \\
(\mathrm{m})\end{array}$ & $\begin{array}{l}\text { Approx. } \\
\text { area of } \\
\text { collections }\end{array}$ & $\begin{array}{l}\text { Scientific } \\
\text { cruises } \\
\text { (n) }\end{array}$ & $\begin{array}{l}\text { Trawl catches } \\
\text { examined } \\
\text { (n) }\end{array}$ & $\begin{array}{c}\text { Fish } \\
\text { families } \\
\text { (n) }\end{array}$ & $\begin{array}{l}\text { Fish } \\
\text { species } \\
\text { (n) }\end{array}$ \\
\hline \multicolumn{7}{|l|}{ Slope depths } \\
\hline $\begin{array}{l}\text { Western } \\
\text { Australia }\end{array}$ & $200-1460$ & $\begin{array}{r}20-35^{\circ} \mathrm{S} \\
112-115^{\circ} \mathrm{E}\end{array}$ & 1 & 151 & 108 & 388 \\
\hline $\begin{array}{l}\text { North } \\
\text { Atlantic }^{\mathrm{a}}\end{array}$ & $\sim 200-2250$ & $\begin{array}{l}20-65^{\circ} \mathrm{N} \\
17-75^{\circ} \mathrm{W}\end{array}$ & 55 & & 57 & 296 \\
\hline $\begin{array}{l}\text { Northeastern } \\
\text { Pacific }^{\text {b }}\end{array}$ & $400-2250$ & $\begin{array}{c}44-46^{\circ} \mathrm{N} \\
125-127^{\circ} \mathrm{W}\end{array}$ & & $>362$ & 18 & 85 \\
\hline $\begin{array}{l}\text { Northwestern } \\
\text { Pacific }^{\mathrm{C}}\end{array}$ & $300-2000$ & $\begin{array}{l}\sim 46-56^{\circ} \mathrm{N} \\
145-154^{\circ} \mathrm{E}\end{array}$ & 1 & 288 & 18 & 114 \\
\hline $\begin{array}{l}\text { Northern } \\
\text { Pacific region }^{\mathrm{d}}\end{array}$ & $300-2250$ & $\begin{array}{l}\sim 44-56^{\circ} \mathrm{N} \\
125-154^{\circ} \mathrm{W}\end{array}$ & & & 19 & 199 \\
\hline \multicolumn{7}{|l|}{ All depths } \\
\hline $\begin{array}{l}\text { North Atlantic } \\
\text { Basin }^{\mathrm{a}}\end{array}$ & $204-5345$ & $\begin{array}{l}20-65^{\circ} \mathrm{N} \\
17-75^{\circ} \mathrm{W}\end{array}$ & 63 & 692 & $\geq 57$ & 325 \\
\hline $\begin{array}{l}\text { Northern } \\
\text { Pacific region }^{\mathrm{d}}\end{array}$ & $300-5180$ & $\begin{array}{l}\sim 44-56^{\circ} \mathrm{N} \\
125-154^{\circ} \mathrm{W}\end{array}$ & & $>885$ & 26 & 204 \\
\hline \multicolumn{7}{|c|}{$\begin{array}{l}\text { a'Summary data for North Atlantic Basin from Haedrich \& Merrett }(1988,1990) \\
\text { bPearcy et al. (1982) } \\
\text { cDudnik \& Dolganov (1992) } \\
\text { d Combined data of Pearcy et al. (1982) and Dudnik \& Dolganov }(1992)\end{array}$} \\
\hline
\end{tabular}


reflect their independent origins in ancient seas prior to the break-up of Gondwana: the Indo-Pacific fauna directly descended from the Tethyan fauna and the southern temperate fauna from a paleoaustral fauna that developed independently along the southern shores of Gondwana (Wilson \& Allen 1987). The notable diversity and isolation of modern shelf and slope faunas of southern and southeastern Australia (Vaughan \& Wells 1943, Poore et al. 1994, Richer de Forges et al. 2000) can be traced back to high levels of endemism in this paleoaustral fauna. Clearly this pattern extends to southwestern Australia, although there are many differences between the slope fish faunas of southeastern and western Australia (see below). We note that the well-known high diversity of the northern shallow-water fauna appears to extend to slope depths as well. The circumglobal extent of the Southern Ocean, along with the considerable age of the temperate and tropical Australian faunas, doubtless contributes to its diversity.

Mixing of faunas is facilitated by the diverse tropical and temperate origins of both near-surface and intermediate-depth water masses that overlap along the western slope region (Fig. 7). Near-surface dispersal is likely to be particularly influenced by the strong seasonal flows of the Leeuwin Current, as it is derived from waters of the Indo-Pacific and flows southwards over the entire length of the western slope into the Great Australian Bight (Smith et al. 1991). In shelf waters it facilitates the polewards movement of tropical fishes into what are exclusively temperate provinces at corresponding latitudes on the western coastlines of other Southern Hemisphere continents (Morgan \& Wells 1991). A countercurrent with warm temperate origins east of Cape Leeuwin flows equatorwards at least as far north as Shark Bay (Pearce 1991). At midslope depths, several intermediate water masses flow adjacent to the slope. North West Indian Intermediate Water (NWIIW) from the northern Indian Ocean extends south to at least $30^{\circ} \mathrm{S}$ with its core layer in about 700 to $1400 \mathrm{~m}$ (Rochford 1961). Banda Intermediate Water (BIW), flowing in a westerly direction south of Indonesia, lies immediately below NWIIW and extends south to $25^{\circ} \mathrm{S}$ in about 800 to $1400 \mathrm{~m}$ (Rochford 1958, 1961). Antarctic Intermediate Water (AIW) flows northwards along the slope and may be derived from 2 widely separated sources. Rochford (1958) described a significant northwards movement of AIW to the southwest of Australia originating from the main eastwards-flowing body south of $40^{\circ} \mathrm{S}$. More recently, circulation models support the possibility of an intermittent westwards flow returning AIW from the Pacific to the Indian Ocean along southern Australia (Bye 1972, Fine 1993).

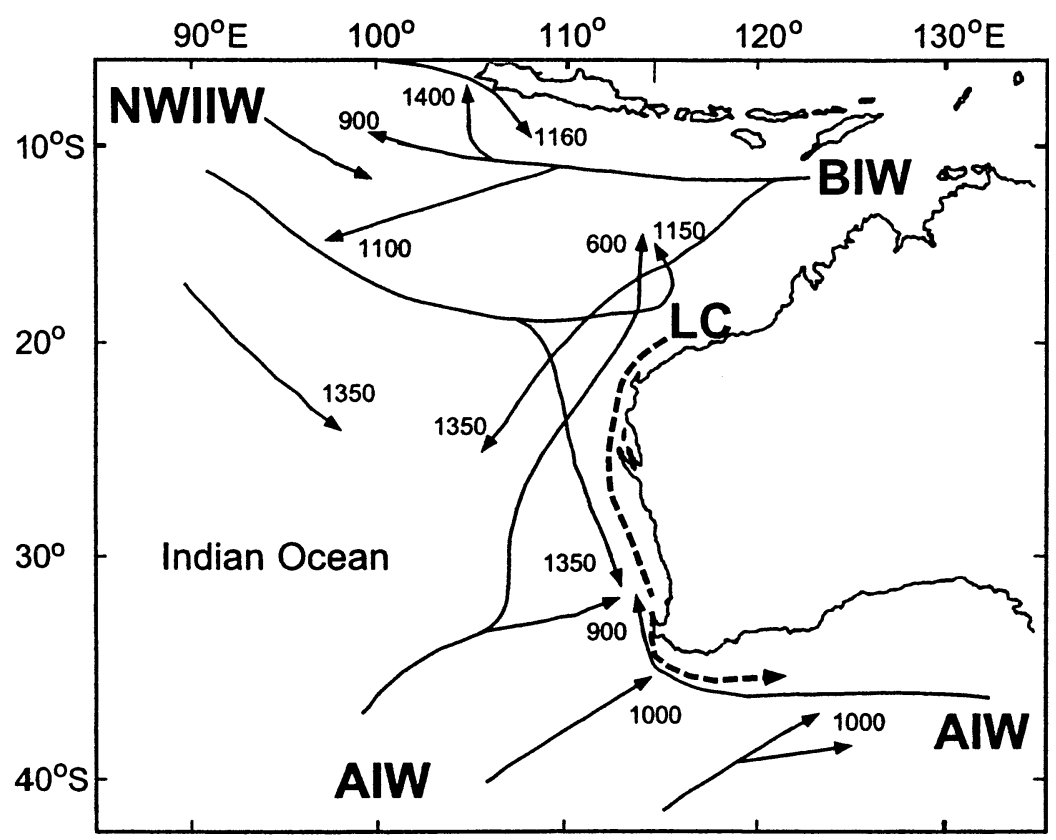

Fig. 7. General features of the primary epipelagic and intermediate ocean currents overlying the continental slope region off the west coast of Australia (redrawn in part from Rochford 1961). NWIIW: North West Indian Intermediate Water; BIW: Banda Intermediate Water; AIW: Antarctic Intermediate Water; LC: Leeuwin Current. Approximate depths (at arrowheads) shown in $\mathrm{m}$

\section{Spatial structure of communities}

Many studies have found depth-related structure in deepwater fish faunas, but patterns along depth gradients may be either zonation (Day \& Pearcy 1968, Menzies et al. 1973, Haedrich et al. 1975, 1980, Pearcy et al. 1982) or the continuous replacement of species (Merrett \& Marshall 1981, Snelgrove \& Haedrich 1985). Off western Australia, bathymetric boundaries were distinct in the slope fish fauna, and zones were defined. Delineation was most distinct between shelf-break and upper-slope communities at about 250 to $350 \mathrm{~m}$, and between upper-slope and mid-slope communities at about 700 to $800 \mathrm{~m}$; shallow and deep communities were also evident on both the upper-slope and mid-slope, with boundaries at about $500 \mathrm{~m}$ and 900 to $1000 \mathrm{~m}$. The robustness of this structure is supported by strong similarities among multivariate groupings formed by abundant species and stations, as well as the high numbers of species contributing to communities in all depth zones. In addition, there were several fre- 
quently occurring indicator species restricted to each community.

The continuity of zonation or community structure and its persistence over more than just local scales (Haedrich \& Merrett 1990) was of interest because there were distinct faunal changes with latitude as well as depth. A surprisingly sharp biotone exists on the mid-slope towards the southern limits $\left(32\right.$ to $\left.33^{\circ} \mathrm{S}\right)$ of the western coastline, while north-south contrasts at the shelf-break, shallow upper-slope and mid-slope indicate that a less-distinct transition zone occurs around 26 to $28^{\circ} \mathrm{S}$ off Shark Bay. On the western mid-slope, only the most southerly community ( 32 to $35^{\circ} \mathrm{S}$ ) was similar to that off southeastern Australia. The degree of overlap $(S=37$ ) was similar to that between southeastern Australia and both the Great Australian Bight (GAB) and Challenger Plateau region off New Zealand (NZ) (Table 5). The overlap of dominant species, which provides a less-conservative measure of overlap when presence/absence data are used from fish communities with high proportions of rarely captured species (Koslow et al. 1994), showed that $58 \%$ were common to the southernmost community off western Australia and southeastern Australia. Levels of similarity declined with decreasing latitude up the west coast, with overlap of the 27 to $32^{\circ} \mathrm{S}$ community and southeastern Australia $(S=24)$ significantly less than that between southeastern Australia, the GAB and NZ (mean; $95 \%$ confidence intervals: $S=41.6 ; 29.6$ to 53.5 ). Despite many widely distributed mid-slope species persisting north of $32^{\circ} \mathrm{S}$ off western Australia, there were few dominant species $(25 \%)$ in common with southeastern Australia. There was an abrupt decrease in overall similarity of the communities north of $27^{\circ} \mathrm{S}$ (Table 5). Upper slope faunas from the 2 regions showed similar patterns to the mid- slope: a comparable degree of similarity with a comparable decline as latitude decreased on the west coast. Both the degree of overlap and number of dominant species in common was slightly higher on the upper slope than on the mid-slope at corresponding latitudes $\left(\sim 22\right.$ to $\left.33^{\circ} \mathrm{S}\right)$, but there were insufficient upper slope samples south of $33^{\circ} \mathrm{S}$ to permit comparison. A biotone in the vicinity of Latitudes 32 and $33^{\circ} \mathrm{S}$ on the southwestern Australian slope therefore appears to be the northwestern boundary of a widely distributed benthopelagic slope fish community; on the mid-slope this community extends over at least $65^{\circ}$ of longitude across southern Australia to New Zealand (Koslow et al. 1994).

Vertical patterns in fish community structure are coincident with the structure of regional hydrology. The faunal discontinuity around $300 \mathrm{~m}$ (the shallow boundary of upper-slope communities) is at the deep limit of the near-surface flow of the Leeuwin Current (Smith et al. 1991). Around 300 m, a physical boundary region exists between southwards flowing, warm, lowsalinity Leeuwin Current water and the cooler, saltier waters of a deeper northwards-moving countercurrent (Pearce 1991). The boundary region between upper and mid-slope communities around $700 \mathrm{~m}$ coincides with the upper extent of AIW off southern Australia (Fine 1993), supporting the suggestion of Koslow et al. (1994) that the mid-slope community off southeastern Australia resides within the core depths of AIW. There is no clear horizontal coincidence in spatial structure as AIW appears to extend well north of the faunal break around 32 to $33^{\circ} \mathrm{S}$ (Rochford 1961). However, flow of AIW in this area may be intermittent (Bye 1972, Fine 1993), and therefore may have a variable influence on the penetration of the southern temperate community into northern waters.

Table 5. Comparison of community composition between the western and southeastern Australian continental slope regions: overlap shown for total species and dominant species only (occurrence $>33 \%$ ) by \% shared in common and the Sorensen $(S)$ coefficient of community. Mid-slope data (800 to $1200 \mathrm{~m}$ ) from SE Australia, Great Australian Bight (GAB) and Challenger Plateau, New Zealand (NZ) from Koslow et al. (1994); upper-slope data (500 m) from May \& Blaber (1989). (Dominant species comparisons based on 24 SE Australian mid-slope species, 29 upper slope species)

\begin{tabular}{|c|c|c|c|c|c|c|}
\hline $\begin{array}{l}\text { Geographical } \\
\text { region }\end{array}$ & $\begin{array}{l}\text { Latitude } \\
\text { range }\left({ }^{\circ} \mathrm{S}\right)\end{array}$ & $\begin{array}{l}\text { No. of } \\
\text { trawls }\end{array}$ & $\begin{array}{c}\text { Total } \\
\text { species }\end{array}$ & $\begin{array}{c}\text { Species in common } \\
\text { with SE Australia (\%) }\end{array}$ & $\begin{array}{l}\text { Sorensen's } \\
\quad S\end{array}$ & $\begin{array}{l}\text { Dominant species in common } \\
\text { with SE Australia (\%) }\end{array}$ \\
\hline \multicolumn{7}{|l|}{ Upper slope } \\
\hline SE Australia & $42-43$ & 41 & 55 & & & \\
\hline Western Australia & $22-27$ & 5 & 64 & 16 & 14.0 & 17 \\
\hline Western Australia & $27-33$ & 8 & 51 & 32 & 31.7 & 35 \\
\hline \multicolumn{7}{|l|}{ Mid-slope } \\
\hline SE Australia & $36-44$ & 376 & 118 & & & \\
\hline Western Australia & $20-22$ & 4 & 40 & 5 & 7.6 & 8 \\
\hline Western Australia & $22-27$ & 7 & 52 & 8 & 10.6 & 8 \\
\hline Western Australia & $27-32$ & 8 & 57 & 18 & 24.0 & 25 \\
\hline Western Australia & $32-35$ & 6 & 55 & 27 & 37.0 & 58 \\
\hline GAB & $33-37$ & 147 & 102 & 42 & 38.2 & 76 \\
\hline NZ & $37-41$ & 181 & 90 & 41 & 39.4 & 81 \\
\hline
\end{tabular}




\section{Fish density and overlying productivity}

Our estimates of demersal fish density on the western Australian slope $\left(<1 \mathrm{~g} \mathrm{~m}^{-2}\right.$ below $\left.400 \mathrm{~m}\right)$ are lower than in many other regions of the world's oceans (Table 6). With the exception of 1 uncharacteristically low estimate from the eastern North Atlantic Ocean (0.2 $\mathrm{g} \mathrm{m}^{-2}$, Merrett et al. 1991), estimates for other regions exceed the density off western Australia by at least 2 to 3 times. Underestimation of density - an inherent bias with the use of small trawl nets (Pearcy et al. 1982, Merrett et al. 1991) —is unlikely to account for our low estimate because a large commercial trawl was used. Of particular interest was that fish-density estimates from the southeastern Australian slope were considerably higher than from the western slope. Those from the upper-slope (Wankowski \& Moulton 1986, May \& Blaber 1989) were 4 to 6 times greater, while an estimate on the southeastern mid-slope (Koslow et al. 1994) was 1 order of magnitude greater (Table 6). Indeed, these comparisons underestimate regional differences: the estimate from the southeastern upper-slope (Wankowski \& Moulton 1986) used a catchability coefficient $(q)$ of $<1$, and excluded several abundant 'non-commercial' species, while the midslope estimate was exclusive of considerable mid-slope fish aggregations undetected by trawl surveys (Koslow et al. 1994).

The low overall density of slope fishes off the west coast of Australia appears to be linked to the low biological productivity of overlying waters. This causal

Table 6. Comparison of demersal slope fish biomass estimates $\left(\mathrm{g} \mathrm{m}^{-2}\right)$ from a range of geographical regions

\begin{tabular}{|c|c|c|c|}
\hline Geographical region & $\begin{array}{c}\text { Depth range } \\
\text { (m) }\end{array}$ & $\begin{array}{l}\text { Sampling } \\
\text { method }\end{array}$ & $\begin{array}{c}\text { Biomass } \\
\left(\mathrm{g} \mathrm{m}^{-2}\right)\end{array}$ \\
\hline Eastern North Atlantic ${ }^{\mathrm{a}}$ & $400-800$ & Variety of trawls & $0.2-12.0$ \\
\hline Eastern North Atlantic ${ }^{\mathrm{a}}$ & $800-1200$ & Variety of trawls & $1.8-13.7$ \\
\hline Western North Atlantic ${ }^{b}$ & $\sim 500-1000$ & Photographic & $2.45-2.72$ \\
\hline Northeastern Pacific ${ }^{\mathrm{c}}$ & $200-1500$ & Variety of trawls & $>1.5-12$ \\
\hline Japan $^{\mathrm{d}}$ & $\sim 500-800$ & Photographic & 4.56 \\
\hline Southeast Australia ${ }^{\mathrm{e}}$ & $300-600$ & $35 \mathrm{~m} \mathrm{trawl}^{\mathrm{h}}$ & 1.7 \\
\hline Southeast Australia $^{\mathrm{f}}$ & 500 & $35 \mathrm{~m} \mathrm{trawl}^{\mathrm{h}}$ & 2.7 \\
\hline Southeast Australia ${ }^{g}$ & $800-1200$ & $35 \mathrm{~m} \mathrm{trawl}^{\mathrm{h}}$ & 4.82 \\
\hline Western Australia & $400-800$ & $35 \mathrm{~m} \mathrm{trawl}^{\mathrm{h}}$ & $0.35-0.57$ \\
\hline Western Australia & $800-1200$ & $35 \mathrm{~m} \mathrm{trawl}^{\mathrm{h}}$ & $0.39-0.56$ \\
\hline \multicolumn{4}{|c|}{${ }^{a}$ Summary data in Merrett et al. (1991) } \\
\hline \multicolumn{4}{|c|}{${ }^{\mathrm{b}}$ Haedrich \& Rowe (1977) } \\
\hline \multicolumn{4}{|c|}{ cSummary data in Pearcy et al. (1982) } \\
\hline \multicolumn{4}{|c|}{${ }^{\mathrm{d}}$ Ohta (1983), data in May \& Blaber (1989) } \\
\hline \multicolumn{4}{|c|}{$\begin{array}{l}\text { eWankowski \& Moulton (1986) (commercial species biomass only; } q=1 \text { ) } \\
\text { data in May \& Blaber (1989) }\end{array}$} \\
\hline \multicolumn{4}{|c|}{${ }^{\mathrm{f}}$ May \& Blaber (1989), data adjusted for $q=1$} \\
\hline \multicolumn{4}{|l|}{${ }^{9}$ Koslow et al. (1994) } \\
\hline \multicolumn{4}{|c|}{${ }^{\mathrm{h}}$ Length in metres is net headline length } \\
\hline
\end{tabular}

association has previously been reported by Lenanton et al. (1991) for fishes on the western continental shelf. Near-surface waters are strongly influenced by the Leeuwin Current that, despite narrowing from about $400 \mathrm{~km}$ off North West Cape to less than $100 \mathrm{~km}$ further south (Cresswell 1991), overlies the relatively narrow slope region (200 to $1500 \mathrm{~m}$ ) that is about $100 \mathrm{~km}$ at its widest point (off Carnarvon) and only $20 \mathrm{~km}$ wide off Cape Leeuwin. The current has maximum speeds just seaward of the shelf-break and can flow strongly at $100 \mathrm{~km}$ further offshore and penetrate to depths of at least $320 \mathrm{~m}$ at $34^{\circ} \mathrm{S}$ (Smith et al. 1991). Unlike eastern boundary currents of the major upwelling regions off South America and southern Africa (Pearce 1991), the Leeuwin Current flows polewards, thereby inducing downwelling rather than upwelling. Being derived from tropical and subtropical waters (Cresswell \& Petersen 1993), it is relatively low in nutrients (Rochford 1980, 1988) and receives no input of nutrients from terrestrial run-off (Lenanton \& Hodgkin 1985). Flow of the West Australian Current northeastwards from the central Indian Ocean (Andrews 1977) and mass transport of surface water (Tranter 1977) also influence the slope, but both are thought to be low in nutrients (G. Cresswell, CSIRO Marine Research, pers. comm.). Surface chlorophyll concentration in the region is low year-round (J. Parslow, CSIRO Marine Research, pers. comm.) and near-surface zooplankton biomass is low in global terms (Tranter 1962). Our observation of increasing fish density with increasing latitude may be attributable to the reduced flow of the Leeuwin Current in summer, and its subsequent displacement by a northerly flowing countercurrent. Cold-water upwellings extend periodically onto the west coast from the Australian south coast, east of Cape Leeuwin (Cresswell \& Petersen 1993, their Plate 1c). A seasonal pulse of production associated with water of temperate origin, which is gradually diluted as it moves northwards, may account for the latitudinal trend in fish density.

Fish density off western Australia was highest at the shelf-break, but at greater depth down the slope, did not vary significantly. This pattern has been observed at high latitudes in the North Pacific (Pearcy et al. 1982), but off southeastern Australia and in some regions of the eastern North Atlantic (Gordon \& Duncan 1985, Merrett et al. 1991) fish biomass is greatest between 750 and $1400 \mathrm{~m}$. Elevated biomass of benthopelagic fishes at mid-slope depths appears to be due to their ability to utilise the mesopelagic micronekton as a 
food source (Gordon \& Duncan 1985) where it is dense and available close to the bottom (Mauchline 1990). Concentrations of mid-slope fishes, and therefore commercial fisheries, occur in some regions where bottom topography, including seamounts, interrupts mesopelagic stratification (Clark et al. 1989, Williams \& Koslow 1997). The vertical distribution and relative abundance of mesopelagic micronekton in our study region is unknown, and the seafloor topography is not yet fully surveyed. However, the lack of elevated fish density at depth, as well as the absence of a mid-slope fishery (after a decade of exploratory commercial fishing), indicates that predation on mesopelagic micronekton does not result in enhanced fish production on the mid-slope off western Australia.

In addition to the observed differences in fish density between the southeastern and western slopes, there appeared to be a contrast in the taxonomic and ecological composition of the respective faunas that may also be related to overlying productivity. A similar, causal association between productivity and horizontal changes in community structure has been made previously for deep-sea fishes (Merrett \& Marshall 1981) including faunas at abyssal depths (Sulak 1982, Merrett 1987, 1998). On Australia's southeastern slope, a few species of relatively large, active, pelagic feeders are highly dominant and support the country's largest fin-fish fisheries: blue grenadier (Macruronus novaezelandiae) on the upper slope (May \& Blaber 1989), and orange roughy (Hoplostethus atlanticus) and oreos (Pseudocyttus maculatus and Allocyttus niger) on the midslope (Koslow 1997). Blue grenadier undertake extensive vertical migrations to feed directly in the epipelagic zone (Clark 1985a,b, Blaber \& Bulman 1987), while orange roughy and oreos feed on components of the deep mesopelagic fauna nearer the bottom (Rosecchi et al. 1988, Clark et al. 1989, Bulman \& Koslow 1992, Williams \& Koslow 1997). These species were rare on the western slope, and no other species of similar size and trophic ecology are dominant or support significant commercial fisheries. Instead, the western slope (below $400 \mathrm{~m}$ ) is characterised by a diverse assemblage in which many relatively small, benthic species or species feeding near the bottom are abundant. The most abundant species and species-groups (in biomass) vary with depth and latitude (Williams et al. 1996), but are predominantly grenadiers (Macrouridae and Bathygadidae), dogfishes (Squalidae) and cucumberfishes (Chlorophthalmidae).

Australia's grenadier fauna, which is dominant on the western slope (Williams et al. 1996, Iwamoto \& Williams 1999) and abundant and species-rich on the southeastern slope (A.W. unpubl. data), provides a similar contrast. External morphological features (McLellan 1977, Howes \& Crimmen 1990) suggest a predominance of benthic and near-bottom pelagic feeders among the western species and active, pelagic feeders among southeastern species. Thus, predominant groups in the western fauna include benthic Caelorinchus species (23.3\% of grenadier biomass) that typically have a well-developed rostrum and small, sub-terminal mouth, and several soft-bodied, near-bottom pelagic forms: Cetonurus globiceps $(20.7 \%)$, Bathygadus spongiceps $(13.5 \%)$ and Gadomus species $(10 \%)$. In contrast, the dominant southeastern species, Coryphaenoides serrulatus (37\% of grenadier biomass), C. subserrulatus $(19.2 \%)$, and Lepidorhynchus denticulatus (31.6\%) are firm-bodied and, at least in regard to the latter 2 species, appear to undertake extensive vertical migrations. Both C. subserrulatus and $L$. denticulatus are commonly caught $>100 \mathrm{~m}$ off the seabed in pelagic trawls (May \& Blaber 1989, A.W. unpubl. data).

The association of high diversity in the western Australian slope fish fauna with low density and low productivity of overlying waters is consistent with studies of other major marine faunas. Plankton communities of the central oceanic gyres (McGowan \& Walker 1978) and the benthos of the abyssal plains (Hessler \& Jumars 1974) are 2 often-noted, exceptionally diverse marine faunas associated with highly oligotrophic environments. However, whether there is an association (negative or otherwise) between productivity and species richness in the deep-sea benthos remains controversial (Rex et al. 1993, Paterson et al. 1998). These ecosystems, including the Indo-Pacific and Southern Ocean continental slope, are all large and very ancient, which may be the key to their high diversity; within limits, productivity may be a less critical factor in determining species diversity.

In summary, the characteristics of fish communities on Australia's western continental slope-rich and diverse composition, distinct vertical structure, low density and predominance of benthic feeding types are consistent with the multiple origins, stratification and low productivity of the ocean currents adjacent to the slope region. Horizontal community patterns indicate that the southern Australian slope fish fauna extends only to the southernmost section of the western slope, with replacement by a northern fauna at all depths as latitude decreases. In contrast to the continental slope off southeastern Australia, the western slope does not appear to support commercial concentrations of fishes.

Acknowledgements. We have pleasure in thanking many colleagues for help with this work: Dr John Paxton of the Australian Museum, Sydney, and Dr Martin Gomon of the Museum of Victoria for fish identification; Kathy Haskard and $\mathrm{Dr} \mathrm{Xi} \mathrm{He}$ for statistical analyses; Mark Lewis and Bruce 
Barker for assistance with the figures; Miroslaw Ryba for writing a computer program used in analyses; David Wright, David Evans, Dr Vicki Wadley, Dr Sebastian Rainer and Naomi Clear for making collections of fishes from commercial fishing vessels; Alastair Graham and Gordon Yearsely for helping to process and catalogue fish specimens; Drs George Cresswell and Steve Rintoul for useful comments on physical oceanography; and Drs Nic Bax and Stephen Blaber, and 2 anonymous referees for critically reviewing an earlier version of the manuscript. We also thank the officers, crew and scientific staff of the FRV 'Southern Surveyor' for help during the trawl survey. This work was part of a project supported by the Fisheries Research and Development Council, Grant No. 1988/74.

\section{LITERATURE CITED}

Andrews JC (1977) Eddy structure and the West Australian Current. Deep-Sea Res 24:1133-1148

Blaber SJM, Bulman CM (1987) Diets of fishes of the upper continental slope of eastern Tasmania: content, calorific values, dietary overlap and trophic relationships. Mar Biol 95:345-356

Bulman CM, Koslow AJ (1992) Diet and food consumption of a deep-sea fish, orange roughy Hoplostethus atlanticus (Pisces: Trachichthyidae), off southeastern Australia. Mar Ecol Prog Ser 82:115-129

Bye JAT (1972) On the circulation of the intermediate water in the southwestern Atlantic Ocean. J Mar Res 19:95-100

Carr MR (1996) PRIMER user manual. Plymouth Marine Laboratory, Plymouth, UK

Clark MR (1985a) The food and feeding of seven fish species from the Campbell Plateau, New Zealand. NZ J Mar Freshw Res 19:339-363

Clark MR (1985b) Feeding relationships of seven fish species from the Campbell Plateau, New Zealand. NZ J Mar Freshw Res 19:365-374

Clark MR, King KJ, McMillan P (1989) The food and feeding relationships of black oreo, Allocyttus niger, smooth oreo, Pseudocyttus maculatus, and eight other fish species from the continental slope of the south-west Chatham Rise, New Zealand. J Fish Biol 35:465-484

Cresswell GR (1991) The Leeuwin Current-observations and recent models. J R Soc West Aust 74:1-14

Cresswell GR, Petersen JL (1993) The Leeuwin Current south of Western Australia. Aust J Mar Freshw Res 44:285-303

Day DS, Pearcy WG (1968) Species associations of benthic fishes on the continental shelf and slope off Oregon. J Fish Res Board Canada 25:2665-2675

Dudnik YI, Dolganov VN (1992) Distribution and abundance of fish on the continental slopes of the Sea of Okhotsk and of the Kuril Islands during the summer of 1989. J Ichthyol 32:58-76

Duhamel G (1995) Revision des genres Centriscops et Notopogon, Macroramphosidae des zones subtropicale et temperee de l'hemisphere sud. Cybium 261-303

Field JG, Clarke KR, Warwick RM (1982) A practical strategy for analysing multispecies distribution patterns. Mar Ecol Prog Ser 8:37-52

Fine RA (1993) Circulation of Antarctic intermediate water in the south Indian Ocean. Deep-Sea Res Part I Oceanogr Res Pap 40:2021-2042

Gomon MF, Glover JCM, Kuiter RH (1994) The fishes of Australia's south coast. State Printer, Adelaide

Gordon JDM, Bergstad OA (1992) Species composition of demersal fish in the Rockall Trough, northeastern Atlantic, as determined by different trawls. J Mar Biol Assoc UK 72: $213-230$

Gordon JDM, Duncan JAR (1985) The ecology of the deepsea benthic and benthopelagic fish on the slopes of the Rockall Trough, northeastern Atlantic. Prog Oceanogr 15: 37-69

Haedrich RL, Merrett NR (1988) Summary atlas of deep-living demersal fishes in the North Atlantic Basin. J Nat Hist 22: 1325-1362

Haedrich RL, Merrett NR (1990) Little evidence for faunal zonation or communities in deep sea demersal fish faunas. Prog Oceanogr 24:239-250

Haedrich RL, Rowe GT (1977) Megafaunal biomass in the deep sea. Nature 269(5624):141-142

Haedrich RL, Rowe GT, Polloni PT (1975) Zonation and faunal compoition of epibenthic populations on the continental slope south of New England. J Mar Res 33:191-212

Haedrich RL, Rowe GT, Polloni P (1980) The megabenthic fauna in the deep sea south of New England, USA. Mar Biol 57:165-179

Heald DI, Walker MH (1982) 'Taiyo Maru 71' demersal trawling cruise in Western Australian coastal waters south of 21ํ․ July-September, 1979. Rep Dept Fish Wildl West Austr 51:1-104

Hessler RR, Jumars PA (1974) Abyssal community analysis from replicate box cores in the central North Pacific. Deep-Sea Res 21:185-209

Howes GJ, Crimmen OA (1990) A review of the Bathygadidae (Teleostei: Gadiformes). Bull Br Mus (Nat Hist) Zool 56: 155-203

Hutchins JB (1994) A survey of the nearshore reef fish fauna of Western Australia's west and south Coasts - the Leeuwin Province. Rec West Aust Mus Suppl 46:1-66

Iwamoto TI, Williams A (1999) Grenadiers (Pisces, Gadiformes) from the continental slope of western and northwestern Australia. Proc Calif Acad Sci, p 105-243

Kloser RJ, JA Koslow, Williams A (1996) Acoustic assessment of the biomass of a spawning aggreation of orange roughy (Hoplostethus atlanticus, Collett) off southeastern Australia, 1990-93. Mar Freshw Res 47:1015-1024

Koslow JA (1997) Seamounts and the ecology of deep-sea fisheries. Am Sci 85:168-176

Koslow JA, Bulman CM, Lyle JM (1994) The mid-slope demersal fish community off south-eastern Australia. DeepSea Res 41:113-141

Last PRL, Harris JGK (1981) New locality records and preliminary information on demersal fish faunal assemblages in Tasmanian waters. Pap Proc R Soc Tasman 115:189-209

Last PRL, Stevens JD (1994) Sharks and rays of Australia. CSIRO Division of Fisheries, Australia

Legendre P, Legendre L (1998) Numerical ecology. Elsevier, Amsterdam

Lenanton RCJ, Hodgkin EP (1985) Life history strategies of fish in some temperate Australian estuaries. In: YanezArancibia A (ed) Fish community ecology in estuaries and coastal lagoons: towards an ecosystem integration. UNAM Press, Mexico, p 267-284

Lenanton RCJ, Joll L, Penn J, Jones K (1991) The influence of the Leeuwin Current on coastal fisheries of Western Australia. J R Soc West Aust 74:101-114

Mauchline J (1990) Aspects of production in a marginal oceanic region, the Rockall Trough, northeastern Atlantic Ocean. Rev Aquat Sci 2:167-183

May JL, Blaber SJM (1989) Benthic and pelagic fish biomass of the upper continental slope off eastern Tasmania. Mar Biol 101:11-25 
McGowan JA, Walker PW (1978) Structure in the copepod community of the north Pacific central gyre. Ecol Monogr 49:195-226

McLellan T (1977) Feeding strategies of the macrourids. Deep-Sea Res 24:1019-1036

Menzies RJ, George RY, Rowe GT (1973) Abyssal environment and ecology of the world oceans. Wiley-Interscience, New York

Merrett NR (1987) A zone of faunal change in assemblages of abyssal demersal fish in the eastern North Atlantic; a response to seasonality in production? Biol Oceanogr 5: $137-151$

Merrett NR (1994) Reproduction in the North Atlantic oceanic ichthyofauna and the relationship between fecundity and species' sizes. Environ Biol Fish 41:207-245

Merrett NR (1998) Demersal ichthyofaunal distribution in the abyssal North Atlantic revisited: the effect of sample size on ordination. Mar Ecol Prog Ser 173:267-274

Merrett NR, Marshall NB (1981) Observations on the ecology of deep-sea bottom living fishes collected off northwest Africa $\left(08^{\circ} \mathrm{N}-27^{\circ} \mathrm{N}\right)$. Prog Oceanogr 9:185-244

Merrett NR, Gordon JDM, Stemann M, Haedrich RL (1991) Deep demersal fish assemblage structure in the Porcupine Seabight (eastern North Atlantic): slope sampling by three different trawls compared. J Mar Biol Assoc UK 71: 329-358

Morgan GJ, Wells, FE (1991) Zoogeographic provinces of the Humboldt, Benguela and Leeuwin Current systems. J R Soc West Aust 74:59-70

Newton G, Klaer N (1991) Deep-sea demersal fisheries resources of the Great Australian Bight: a multivesssel trawl survey. Bull Bur Rural Resour Canberra 10:1-71

Ohta S (1983) Photographic census of large-sized benthic organisms in the bathyal zone of Suruga Bay, Central Japan. Bull Ocean Res Inst Univ Tokyo 15:1-344

Paterson GLJ, Wilson GDF, Cosson N, Lamont PA (1998) Hessler and Jumars (1974) revisited: abyssal polychaete assemblages from the Atlantic and Pacific. Deep-Sea Res Part II Top Stud Oceanogr 45:225-251

Paxton JR, Hoese DF, Allen GR, Hanley JE (1989) Zoological catalogue of Australia, Vol 7. PISCES-Petromyzontidae to Carangidae. Australian Government Publishing Service, Canberra

Pearce AF (1991) Eastern boundary currents of the Southern Hemisphere. J R Soc West Aust 74:35-45

Pearcy WG, Stein DL, Carney RS (1982) The deep-sea benthic fish fauna of the northeastern Pacific Ocean on Cascadia and Tufts abyssal plains and adjoining continental slopes. Biol Oceanogr 1:375-428

Poore GCB, Just J, Cohen BF (1994) Composition and diversity of Crustacea Isopoda of the southeastern Australian continental slope. Deep-Sea Res 41:677-693

Rex MA, Stuart CT, Hessler RR, Allen JA, Sanders HL, Wilson FDF (1993) Global-scale latitudinal patterns of species diversity in the deep-sea benthos. Nature 365:636-639

Richer de Forges B, Koslow JA, Poore GCB (2000) Diversity and endemism of the benthic seamount fauna in the southwest Pacific. Nature 405:944-947

Rochford DJ (1958) Characteristics and flow paths of the intermediate depth waters of the southeast Indian Ocean. J Mar Res 17:483-504

Rochford DJ (1961) Hydrology of the Indian Ocean. I. The

Editorial responsibility: Tony Underwood (Contributing

Editor), Sydney, New South Wales, Australia water masses in intermediate depths of the southeast Indian Ocean. Aust J Mar Freshw Res 12:129-149

Rochford DJ (1980) Nutrient status of the oceans around Australia. Annu Rep CSIRO Fish Oceanogr, 1977-1979:9-20

Rochford DJ (1988) Seasonal influx of nitrates to the slope and shelf waters off north-west Australia. Rep Mar Lab CSIRO, Aust 191:1-23

Rosecchi E, Tracey DM, Webber WR (1988) Diet of orange roughy, Hoplostethus atlanticus (Pisces: Trachichthyidae), on the Challenger Plateau, New Zealand. Mar Biol 99: 293-306

Smith MM, Heemstra PC (eds) (1986) Smiths' sea fishes. Springer-Verlag, Berlin

Smith RL, Huyer A, Godfrey JS, Church JA (1991) The Leeuwin Current off Western Australia, 1986-1987. J Phys Oceanogr 21:323-345

Snelgrove PVR, Haedrich RL (1985) Structure of the deep demersal fish fauna off Newfoundland. Mar Ecol Prog Ser 27:99-107

Steel RGD, Torrie JH (1981) Principles and procedures of statistics; a biometrical approach. McGraw-Hill Inc, Tokyo

Sulak KJ (1982) A comparative taxonomic and ecological analysis of temperate and tropical demersal deep-sea fish faunas in the western North Atlantic. PhD dissertation, University of Miami, FL

ter Braak CJF (1988) CANOCO. Agricultural Mathematics Group. Tech Rep LWA-88-02, Wageningen

ter Braak CJF, Smilauer P (1998) CANOCO reference manual and users guide to Canoco for Windows: software for canonical community ordination (version 4). Microcomputer Power, Ithaca, NY

Tranter DJ (1962) Zooplankton abundance in Australasian waters. Aust J Mar Freshw Res 13:106-142

Tranter DJ (1977) Further studies of plankton ecosystems in the eastern Indian Ocean. I. Introduction - the study and the study area. Aust J Mar Freshw Res 28:529-539

Vaughan TW, Wells JW (1943) Revision of the suborders, families, and genera of the Scleractiina. Geol Soc Am Spec Pap 44:1-363

Wankowski JWJ, Moulton PL (1986) Distribution, abundance and biomass estimates of commerically important demersal fish species in eastern Bass Strait, Australia. Tech Rep Dep Cons Lands Fish Wildl Serv No. 62:1-57

Williams A, Koslow JA (1997) Species composition, biomass and vertical distribution of micronekton over the midslope region off southern Tasmania, Australia. Mar Biol 130:259-276

Williams A, Last PRL, Gomon MF, Paxton JR (1996) Species composition and checklist of the demersal ichthyofauna of the continental slope off Western Australia (20-35 $\mathrm{S})$. Rec West Aust Mus 18:135-155

Wilson BR, Allen GR (1987) Major components and distribution of marine fauna. In: Dyne GR, Walton DW (eds) The fauna of Australia. General Articles Bureau of Flora and Fauna, Australian Government Publishing Service, Canberra, p 43-68

Yearsley GK, Last PRL, Morris GB (1997) Codes for Australian aquatic biota (CAAB): an upgraded and expanded species coding system for Australian fisheries databases. Rep Mar Lab CSIRO, Aust 224:1-15

Zar JH (1996) Biostatistical analysis, 3rd edn. Prentice Hall Inc, Upper Saddle River, NJ

Submitted: May 2, 1999; Accepted: August 9, 2000

Proofs received from author(s): February 12, 2001 